Original Article

\title{
Adolescent rape: Characteristics and short-term impact
}

\author{
Titis Prawitasari, Hartono Gunardi, Bambang Madiyono, \\ Rosdiana S Tarigan
}

\begin{abstract}
Background Data in Indonesia show that adolescents still have the highest rate for rape and other sexual assaults among age group. There are gender differences in adolescent rape and sexual assault, with female victims exceeding males with a ratio of 3:1. Sexual assault and rape can affect numerous children and often lead to short-term and long-term consequences.

Objectives To determine the characteristics and short-term impacts of adolescent rape.

Methods A cross-sectional study was conducted on 31 adolescents who had been raped 1-9 months previously. Subjects and parents were assessed using Child Behavior Checklist, Draw a Person, House Tree Person, and Raven's Progressive Matrices to determine psychological problems. History and physical examination findings at the time of rape were reviewed.

Results Thirty out of 31 female adolescents were 13-18 years old. Almost half of them came from low income families and large families, two-thirds of all subjects were living with their parents. Nineteen of 31 perpetrators were friends or acquaintances, only 4 were relatives. Tears of hymen were found in 21 subjects and only 8 of them had non-genital injuries. Nine of 31 subjects had a high average range in non-verbal processing. Most subjects had a great tendency to feel insecure, anxiety, depression, and had interpersonal relationship problems. Regression and aggressiveness were found in almost half of the subjects. All subjects felt that their mothers were protective and half of them had dominant fathers.

Conclusion Almost half of the adolescent victims come from loweconomic status and large families, most of the assailants were friends or acquaintances. Adolescent rape victims have ongoing behaviour problems. The most common problems are anxiety, depression, and relationship problems [Pediatr Indones 2005;45:246-250].
\end{abstract}

Keywords: rape, adolescent rape, sexual assault, child behaviour checklist
S exual assault is a comprehensive term that encompasses a wide range of sexual victimizations, including rape. Pusat Krisis Terpadu (PKT) or Suspected Child Abuse and Neglect Center (SCAN) at Cipto Mangunkusumo Hospital reported that from June 2000-December 2003, there were 431 rape victims under 18 years old and 418 molested cases both male and female under 18 years old. The major proportion of rape victims are ages 12 17 years. ${ }^{1}$ There are significant gender differences in adolescent rape and sexual assault with female and male ratio of $3: 10^{2,3}$ Children from low socio-economic status, extended families, or single-parent families have higher risk than others. ${ }^{3,4}$ Snyder ${ }^{1}$ and Jones ${ }^{5}$ have also demonstrated that two-thirds to threequarters of adolescent rapes are perpetrated by an acquaintance or a relative of the victim. Adolescent victims are more likely to have used drugs or alcohol

Presented at The $13^{\text {th }}$ National Child Health Congress, Bandung, Indonesia, 4-7 Juli 2005.

From the Department of Child Health, Medical School, University of Indonesia, Jakarta, Indonesia (TP, HG, BM) and the Faculty of Psychology, University of Indonesia, Jakarta, Indonesia (RST)

Reprint requests to: Titis Prawitasari, MD, Department of Child Health, Medical School, University of Indonesia, Cipto Mangunkusumo Hospital, Jl. Salemba Raya 6, Jakarta. Tel. 62-21-3907742, Fax. 62-21-3907743; Email: tprawitasari@yahoo.com 
and less likely to be physically injured during rape. Adolescent female victims are also more likely to delay seeking medical care after rape. ${ }^{2}$

Short-term impacts of adolescent rape have been documented. These may include depression, inferiority, anxiety, school and behaviour problems, sense of powerlessness, and hopelessness for the future. Longterm consequences may also include some persisting effects of short-term effect and increased risk of additional victimization. Somatic problems, eating disorders, relationship difficulties, drugs abuse, attempted suicide, self injury, and criminal activity may also manifest in later life. ${ }^{6}$ The aim of this study is to determine the characteristics of adolescent rape and its shortterm impacts.

\section{Methods}

The sample comprised of 90 female children who were been raped during the period of 1 January-30 August 2004 and came to the PKT or SCAN Center, Cipto Mangukusumo Hospital. These children were between 12-18 years of age and resided either in Jakarta, Bogor, Tangerang, or Bekasi. All had experienced some form of forced sexual intercourse; including vaginal, anal, or oral penetration by the perpetrator. Rape definition also includes penetration with foreign objects or situations in which the victims were unable to give consent because of intoxication. The child behaviour checklist (CBCL) was completed by the parents to assess their children's behaviour. A t-score of $>70$ was categorized as clinical range. Demographic data and details about the rape were collected by the doctor in charge at SCAN center. Per capita income was grouped into poor ( $\leq$ Rp130,499.00/capita/month) and middle low (>Rp130,499.00/capita/month) according to Indonesia's National Bureau of Statistics, 2002. Draw A Person (DAP), House Tree Person (HTP), and Raven's Progressive Matrices (RPM) were done by all subjects and interpreted by a pediatric psychologist. Since posttraumatic stress disorders usually begin within the first 3 months after trauma, we classified the results of behavior problem into 2 groups, $\leq 3$ months or $>3$ months. Data were processed by SPSS version 12.0 for Windows. The study was approved by the Committee of the Medical Research Ethics of the Medical Faculty, University of Indonesia.

\section{Results}

Of 90 cases, 49 could not be traced or removed from the old address and 10 refused to participate. This remained 31 subjects; thirty of them were between 13-18 years of age (mean 15.5 years; SD 1.8). Twenty one of 31 patients were in junior or senior high school. Two third of the subjects were living with their own parents, only 3 of 31 were living with a single parent. Most of the parents were above 30 years old and only 1 had higher education. Domestic violence was identified in 6 families and 4 out of 31 had substance abuse. Table 1 shows demographic characteristics.

Eighteen of 31 rape cases occurred in the residence of the victim or the perpetrator. Ten cases happened before noon. All the assailants were male, mostly 20-24 years of age (mean 28.8 years; SD 11.8). Most of the victims are perpetrated by their friend, including their boyfriend (5 of 18 cases). There were 10 subjects out of 31 being raped more than 1 time and 5 cases had more than 1 assailant (Table 1). Of the recorded genital injuries, 21 subjects had tears of hymen, 2 subjects had laceration of the labia minora, 4 subjects had laceration in posterior fourchette, and 4 subjects had hematoma or laceration at perianal area. There were 10 subjects with no hymenal injury. Only a minority of the subjects had non-genital injuries ( 8 of 31 had skin bruises, laceration and hematoma).

Table 2 shows that twenty four subjects had problems in internalizing, externalizing, or both. It also shows that three months after rape, there was an increasing number of subjects who had behavior problems. There were 7 subjects without behaviour problems according to CBCL. If we look at CBCL results per sub-scale, anxious/depression subscale was the most common behaviour problem complained by parents or caregivers followed by attention and thinking problem (Figure 1). These figures also show that for both borderline and clinical range, internalizing behaviours (withdrawn, somatic problem, anxiety/ depression) tend to be higher than externalizing behaviours (delinquent and aggressive behaviour).

There were 22 of 31 subjects who had low average range in non-verbal processing using RPM. All DAP and HTP results were formally interpreted. Most subjects had a great tendency to feel insecure, anxious, depressed and had interpersonal relationship problems. 
Table 1. Characteristics of adolescent rape victims at Pusat Krisis Terpadu Cipto Mangunkusumo Hospital

\begin{tabular}{|c|c|}
\hline Characteristics & $\begin{array}{l}\text { Cases } \\
(\mathrm{n}=31)\end{array}$ \\
\hline \multicolumn{2}{|l|}{ Age (years) } \\
\hline $12-14$ & 11 \\
\hline $15-18$ & 20 \\
\hline \multicolumn{2}{|l|}{ Socioeconomic status } \\
\hline Poor & 18 \\
\hline Middle low & 13 \\
\hline \multicolumn{2}{|l|}{ Rearing status } \\
\hline Parents & 21 \\
\hline Single parent & 3 \\
\hline Step mother/father & 2 \\
\hline Caregiver & 5 \\
\hline \multicolumn{2}{|l|}{ Number of children in the family } \\
\hline$>4$ children & 14 \\
\hline$\leq 4$ children & 17 \\
\hline \multicolumn{2}{|l|}{ Time of rape } \\
\hline 6-12 a.m. & 10 \\
\hline $12-6$ p.m. & 6 \\
\hline 6-12 p.m. & 11 \\
\hline $12-6$ a.m. & 4 \\
\hline \multicolumn{2}{|l|}{ Location } \\
\hline Perpetrator residence & 11 \\
\hline Victim residence & 7 \\
\hline Other residence & 3 \\
\hline Non-residence (e.g. field, park or roadway) & 10 \\
\hline \multicolumn{2}{|l|}{ Perpetrator } \\
\hline$>1$ & 5 \\
\hline 1 & 26 \\
\hline \multicolumn{2}{|l|}{ Frequency of rape } \\
\hline$>1$ & 10 \\
\hline 1 & 21 \\
\hline \multicolumn{2}{|l|}{ Relationship of perpetrator and victim } \\
\hline Parent & 2 \\
\hline Relative & 2 \\
\hline Friend & 13 \\
\hline Acquaintance & 6 \\
\hline Neighbour & 6 \\
\hline Stranger & 2 \\
\hline
\end{tabular}

Almost half of 31 subjects showed regression and aggressiveness. All subjects felt that their mothers were protective and half of them had dominant fathers, but they felt that family was important. Only 9 subjects had a high average range in RPM could fully interpret (results are resumed in Table 3). Of 9 cases, almost half of them were emotionally immature, regressive, and had high sexual impulse. Most of them tend to withdraw from conflict and want to be more independent. Anxiety, inferiority, and dependency were also their present problems. Adaptation and relationship were good in 5 of 9 subjects.

\section{Discussion}

This study was a preliminary study which comprised of 31 female adolescent victims between $12-18$ years of age. Half of them came from low income families and had large families. These facts were already documented in various studies before. ${ }^{3,4}$ Different from other studies, we found that only a minority of subjects $(10 \%)$ came from single parent families. Indonesian culture factors might have influence on this result.

Most adolescent rapes occured in the victim's or perpetrator's residence. Almost all assailants were familiar to the victims, most of them were friends (including their boyfriend) and acquaintances. Snyder ${ }^{1}$ and Jones et al found the same results and stated that the perpetrators of the younger victims are more likely to be a member of their own extended family while

Table 2. Behaviour problems of adolescent rape victim at Pusat Krisis Terpadu Cipto Mangunkusumo Hospital

\begin{tabular}{lccc}
\hline \multirow{2}{*}{ Behaviour problem } & \multicolumn{3}{c}{ Duration } \\
\cline { 2 - 4 } & $\mathbf{3}$ months & $\mathbf{3}$ months & Total \\
\cline { 2 - 4 } & $\mathbf{n = 7}$ & $\mathbf{n = 2 4}$ & $\mathbf{n = 3 1}$ \\
\hline $\begin{array}{l}\text { Internalizing* } \\
\text { Borderline } \\
\quad \text { Clinical range }\end{array}$ & 0 & 3 & 3 \\
Externalizing & 5 & 14 & 19 \\
$\quad$ Borderline & & 1 & 2 \\
$\quad$ Clinical range & 1 & 13 & 15 \\
Internalizing \& Externalizing & 2 & & 10 \\
$\quad$ Clinical range & 2 & 4 & 7 \\
None & 3 & & \\
* internalizing consists of: withdrawn, somatic problem, anxiety/depressed \\
\# externalizing consists of: delinquent behavior and aggressive behavior
\end{tabular}




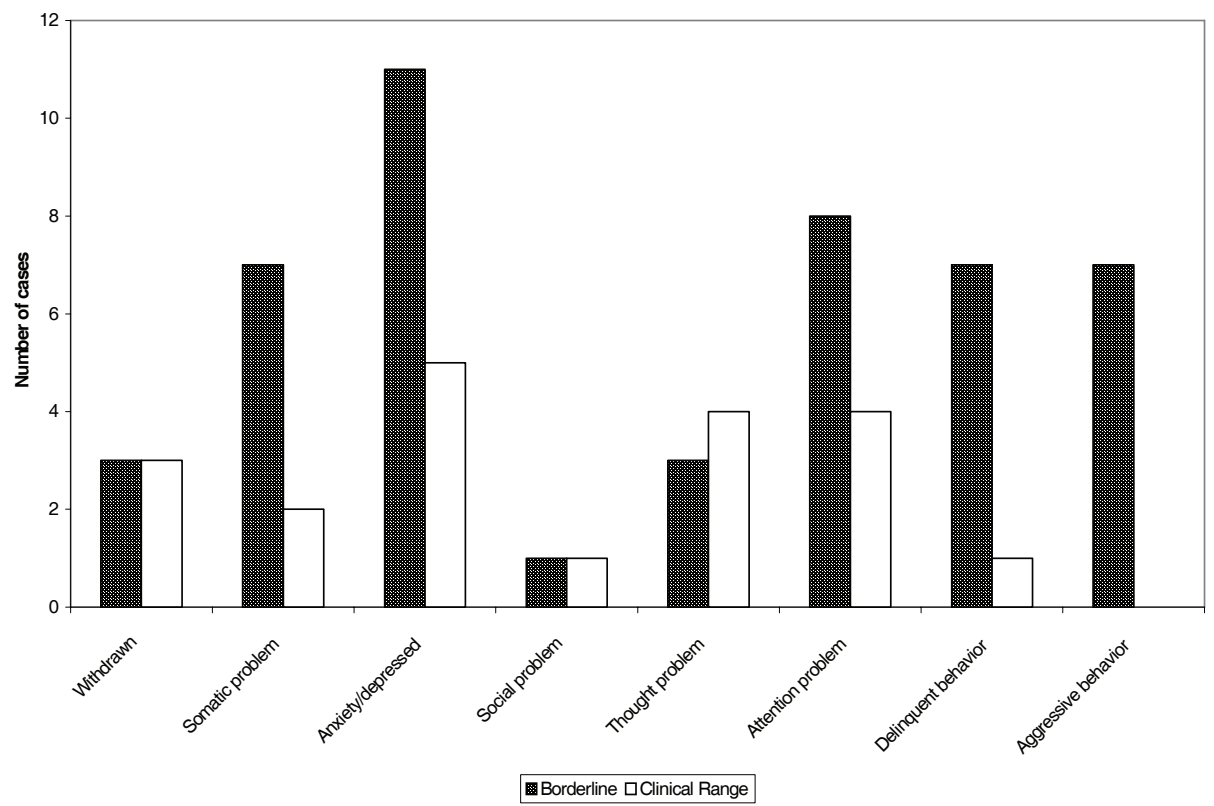

Figure 1. Child behaviour Checklist subscales of adolescent rape Victims at pusat Krisis Terpadu Cipto Mangunkusumo Hospital

Table 3. Interpretation of Draw a Person and House Tree Person of nine adolescent rape victims at Pusat Krisis Terpadu Cipto Mangunkusumo Hospital

\begin{tabular}{|c|c|c|c|c|c|}
\hline Case & $\begin{array}{c}\text { Inter } \\
\text { personal } \\
\text { relation }\end{array}$ & $\begin{array}{c}\text { Emotional } \\
\text { control }\end{array}$ & Present Problems & Defenses & Expectancies \\
\hline No. 1 & good & appropriate & sexual impulse & $\begin{array}{l}\text { withdrawing from } \\
\text { conflict }\end{array}$ & independent \\
\hline No. 2 & good & immature & uncertainty & $\begin{array}{c}\text { regression, } \\
\text { withdrawing from } \\
\text { conflict }\end{array}$ & - \\
\hline No. 3 & poor & immature & dependency, & $\begin{array}{c}\text { regression, } \\
\text { withdrawing from } \\
\text { conflict }\end{array}$ & independent \\
\hline No. 4 & poor & immature & $\begin{array}{l}\text { dependency, } \\
\text { powerlessness }\end{array}$ & $\begin{array}{c}\text { aggressive, } \\
\text { withdrawing from } \\
\text { conflict }\end{array}$ & $\begin{array}{l}\text { different figure, } \\
\text { stronger }\end{array}$ \\
\hline No. 5 & good & immature & $\begin{array}{l}\text { anxiety, inferiority, } \\
\text { low self esteem, } \\
\text { sexual impulse }\end{array}$ & $\begin{array}{c}\text { regression, } \\
\text { withdrawing from } \\
\text { conflict }\end{array}$ & independent \\
\hline No. 6 & poor & immature & $\begin{array}{l}\text { anxiety, inferiority, } \\
\text { low self esteem, } \\
\text { sexual impulse }\end{array}$ & $\begin{array}{c}\text { regression, } \\
\text { ignorance }\end{array}$ & independent \\
\hline No. 7 & good & appropriate & $\begin{array}{l}\text { anxiety, depressed, } \\
\text { low self esteem, } \\
\text { sexual impulse }\end{array}$ & $\begin{array}{c}\text { fantasy, } \\
\text { withdrawing from } \\
\text { conflict }\end{array}$ & - \\
\hline No. 8 & good & inappropriate & anxiety, sexual impulse & aggressive & independent \\
\hline No. 9 & poor & appropriate & $\begin{array}{l}\text { depressed, dependency, } \\
\text { inferiority, sexual impulse }\end{array}$ & $\begin{array}{l}\text { withdrawing from } \\
\text { conflict }\end{array}$ & independent \\
\hline
\end{tabular}

strangers are usually the offender of adult victims. Older adolescents were most commonly raped during or after social encounters with the assailants. ${ }^{1}$ Only 10 subjects seeked for medical care and reported to the authority within 72 hours after rape as recommended by the American Academy of Pediatrics. ${ }^{7}$ Humiliation, self-blame, and naiveté may be the reasons for victims not to seek medical care. ${ }^{2}$ 
Snyder ${ }^{1}$ noted that the time of the day of the rape was related to the age of the victims. For adult victims, sexual assaults most commonly happened between midnight and 2 a.m., and for young victims this crime peak was in $3 \mathrm{p} . \mathrm{m}$. The temporal patterns of adolescent sexual assault appeared to be in combination with the pattern of the young and adult victims. ${ }^{1}$ Our study had different results; adolescent rape mostly occurred between 6 a.m. until noon when no one was at home; or 6 p.m. until midnight after the victims had social encounter with the perpetrator.

Rape trauma syndrome is described as an initial phase lasting days to weeks during which the victim experiences fear, anxiety, no self confidence, and guilty feeling followed by a reorganization phase lasting months to years during which the victims go through periods of adjustment and recovery. ${ }^{2}$ Anxiety, depression, inferiority, and insecurity are the most found psychological problems which occurred in our victims. Oates ${ }^{8}$ suggested that depression may be an immediate response to the trauma, with some children improving in the first 18 months. Swanston ${ }^{6}$ stated that until 5 years after presentation and diagnosis of sexual abuse, victims were significantly more anxious or depressed and had significant inferiority and exhibited more significant behaviour problems than children of non-abused comparison group. Our data showed that anxiety/depression is the most common problem and tends to increase after 3 months.

The role of family is important in the victim recovery. ${ }^{4}$ Although the mothers are protective and half of the fathers were dominant, we found that a majority of the subjects felt that their parents and families support them. Usually adolescent victims put more interest in all matters outside the family, after 3 months.

Not all sexually abused children have serious psychiatric sequelae. Up to $40 \%$ of sexually abused children may present with few or no symptoms, and our data revealed only about 20\%. These conditions are based on a number of reasons including the possibility that they had minor abuse, they are more resilient, or that they have a copying style to mask their stress. However other data suggested that $10-20 \%$ of asymptomatic children will deteriorate over the next 12-18 months. ${ }^{9}$

In conclusion, we found that most of our victims have ongoing psychological problems. Anxiety, depression, inferiority, and insecurity are the most psy- chological problems. Half of them come from low economic status and have large families; most of the perpetrators are their friends and acquaintances. A longitudinal study is the best design to know exactly the ongoing problems and rape impacts.

It is important for pediatricians to not only manage the physical needs of the victims, but to also be sensitive to their psychological needs. Pediatricians should be aware of the services in community that provide management, examination and counseling for adolescents who had been raped.

\section{References}

1. Snyder HN. Sexual assault of young children as reported to law enforcement: victims, incident and offender characteristics. Washington DC: US Department of Justice, Office of Justice Programs; 2000. p. 1-14.

2. American Academy of Pediatrics, Committee on Adolescence. Care of the adolescent sexual assault victim. Pediatrics 2001;107:1477-9.

3. Finkel MA, De Jong AR. Medical findings in child sexual abuse. In: Reece RM, editor. Child abuse: Medical diagnosis and management. Baltimore: William \& Wilkins; 1996. p. 185-247.

4. Mullen PE, Martin JL, Anderson JC, Romans SE, Herbison GP. The effect of child sexual abuse on social, interpersonal and sexual function in adult life. $\mathrm{Br}$ J Psychiatry 1994;165:35-47.

5. Jones JS, Rossman L, Wynn B, Dunnuck C, Schwartz N. Comparative analysis of adult versus adolescent sexual assault: Epidemiology and pattern of anogenital injury. Acad Emerg Med 2003;10:872-7.

6. Swanston HY, Tebbutt JS, O'Toole BI, Oates RK. Sexually abused children 5 years after presentation: A casecontrol study. Pediatrics 1997;100:600-8.

7. American Academy of Pediatrics, Committee on Child Abuse and Neglect. Guidelines for the evaluation of sexual abuse of children: Subject review. Pediatrics 1999;103:186-91.

8. Oates KR, O'toole B, Lynch DL, Stern A, Cooney G. Stability and change in outcome for sexually abused children. J Am Acad Child Adolesc Psychiatry 1994;33:945-53.

9. Putnam FW. Ten-year research updates review: Child sexual abuse. J Am Acad Child Adolesc Psychiatry 2003;42:269-78. 